\title{
An Exploration of The Role of Blockchain in The Sustainability and Effectiveness of The Pharmaceutical Supply Chain
}

\author{
Shaker ALHARTHI, Paul R. CEROTTI and Shaghayegh MALEKI FAR \\ RMIT University, Melbourne, Australia \\ Correspondence should be addressed to: Shaker ALHARTHI; s3402132@student.rmit.edu.au
}

Received date: 10 March 2020; Accepted date : 27 July 2020; Published date: 6 October 2020

Academic Editor: Mohamed Nejib Ouertani

Copyright (C) 2020. Shaker ALHARTHI, Paul R. CEROTTI and Shaghayegh MALEKI FAR. Distributed under Creative Commons Attribution 4.0 International CC-BY 4.0

\begin{abstract}
The main aim of this study is to explore the role of blockchain technology in the sustainability and effectiveness of the pharmaceutical supply chain in the Kingdom of Saudi Arabia (KSA). The objectives of this study are: to explore the opportunities for the blockchain technology to address the existing problems in the pharmaceutical supply chain; to uncover the barriers and challenges of blockchain adoption and implementation; to develop guidelines for a successful implementation of blockchain in the context of Saudi Arabia; and to investigate the perceptions of professionals about the impact of blockchain adoption in the pharmaceutical supply chain sector. The researchers have identified issues surrounding the lack of integration of IT systems in the healthcare systems in KSA. Further problems have been identified: such as medication shortage, lack of coordination among healthcare stakeholders, product wastage and lack of medication demand information. Blockchain, as a distributed digital ledger technology which ensures transparency, traceability and security, is considered as a promise for easing some supply chain management problems. The evaluation of the impact of 'Technology, Organisation, Environment' (TOE) theory, will provide a clear picture to comprehend the influence of these factors on the sustainability of the supply chain, and thus the supply chain effectiveness. This study provides a theoretical model for the impact of blockchain implementation on the sustainability and effectiveness of the pharmaceutical supply chain. Researchers highlighted issues in the current management of the pharmaceutical supply chain and explained how blockchain can be used to solve these problems and how blockchain can address and support the sustainability of supply chains. While the technology of blockchain is definitely in its infancy, the researchers have already seen success in its everyday deployment, especially in the pharmaceutical and financial sectors.
\end{abstract}

Keyword: Blockchain, Sustainability, Supply chain, Pharmaceutical, Saudi Arabia, IT Integration.

Cite this Article as: Shaker ALHARTHI,Paul R. CEROTTI and Shaghayegh MALEKI FAR (2020), "An Exploration of The Role of Blockchain in The Sustainability and Effectiveness of The Pharmaceutical Supply Chain" Journal of Supply Chain and Customer Relationship Management, Vol. 2020 (2020), Article ID 562376, DOI: $10.5171 / 2020.562376$ 


\section{Introduction}

The following two topics have acquired more importance in recent years in supply chain management (SCM). Firstly, sustainable supply chain management (SSCM), which has already received significant attention from many researchers (Lin, Tseng \& Pai, 2018). Secondly, information technology (IT) has been progressively considered as a key efficiency factor in the supply chain (Ata, 2015). IT contributes to the sustainable development of supply chain operations, which is considered as one of the most important sectors where high quality logistics management is needed (Fiorini \& Jabbour, 2017). Overall, any process of using resources, technology development, directing investments and institutional changes that are compatible with the needs of the present beside the future, can be called sustainable development (Rana \& Alayed, 2018).

There are five major health authorities in the Kingdom of Saudia Arabia (KSA): the Ministry of Health (MOH), the Medical Services of the Armed Forces (MSAF), King Faisal Specialist Hospital and Research Center (KFSH\&RC), the Ministry of National Guard Health Affairs (MNGHA), and the Security Forces Hospitals (SFH). These health authorities provide healthcare services in KSA; however, there is a lack of IT integration among them (Alsulame, Khalifa \& Househ, 2016). Additionally, Khalifa (2014) states that insufficient electronic data exchange and poor integration among different Saudi hospitals' IS modules and other electronic systems have been identified as another barrier to the successful use of IS in hospitals. Furthermore, due to the insufficient number of healthcare practitioners and the lack of technology applications, the e-health system in KSA has been lagging behind the developed countries around the world (Alyami, 2018).

These shortages have resulted in certain problems such as medication shortage, lack of coordination among healthcare stakeholders, product wastage, and lack of medication demand information (Alruthia et al. 2018; Kapoor, D., Vyas \& Dadarwal, 2018; Privett \& Gonsalvez, 2014). In addition, many hospitals in KSA have poor pharmaceutical supply chain systems (Alruthia et al. 2018). Hence, in this research, these prevalent issues will be addressed, and the results will help to improve the current system in a way that fills the current gaps in the system and ensures greater benefits in line with the Kingdom's digital transformation visions.

According to the Saudi Vision (2019), the Ministry of Health (MOH) seeks to preserve the environment by relying on technology to implement internal transactions and provide services to citizens in an electronic form, which means electronic paperless services provided to the beneficiary everywhere. The MOH aims to preserve the environment and strives to achieve sustainability in all its electronic services (Ministry of health, 2019; Rana \& Alayed, 2018). Thus, one of the most significant goals of KSA's vision is to adopt and implement modern technologies in order to serve the society and collect enough basic data to allow a proper development planning (Saudi Vision, 2019).

There are several IT applications which can be used to organise whole records in healthcare facilities. Electronic Data Interchange (EDI), Enterprise Resource Planning (ERP), and Radio Frequency Identification (RFID) are some of the potential IT applications (Fiaidhi, Mohammed \& Mohammed, 2018; Georgise, Klause-Dieter \& Seifert, 2014). Additionally, blockchain is one possible technology to enhance integrity, authenticity, and consistency of stored and exchanged medical records. Blockchain offers a shared and transparent history of all the transactions to create trust, accountability, decentralisation, transparency, and immutability applications. Moreover, blockchain addresses security issues associated with a deployed distributed patient records database that could be managed by different advisories such as caregivers, hospitals, pharmacies, insurance companies, regulators and the patients (Alhadhrami et al. 2017). Blockchain is also an appropriate solution when it is required 
to document a patient's health record or to secure a medications' movement through the supply chain (Sadiku, Eze \& Musa, 2018).

The execution of supply chain technologies can enable organisations to improve efficiency, facilitating traceability and managing distributions networks (Hellen \& Patrick, 2019). The challenges faced by the supply chain sector can be reduced or even avoided by using blockchain technology, and sustainability can be greatly improved (Tijan et al. 2019). However, blockchain and sustainable integration have been somewhat neglected in academic research; therefore, more studies should be conducted to investigate the potential use of blockchain in the area of the sustainable supply chain (Queiroz, Telles \& Bonilla, 2019; Schmidt \& Wagner, 2019).

This research applies the Technology Readiness Index Theory (TRI) and the Technology, Organisation, Environment (TOE) framework to explore the role of blockchain in the sustainability and effectiveness of the pharmaceutical supply chain in Saudi Arabia. TOE reflects the integration of the environmental construct as a variable together with the existing technology and organisation constructs (Bokolo, 2020). This study will use a qualitative method approach to collect data from Saudi Arabia hospitals, which will be analysed using thematic analysis.

\section{Literature Review}

This chapter focuses on the literature pertaining to blockchain (BC), sustainable supply chain management (SSCM) and information technology (IT). It discusses the study's theoretical basis, the concept of SSCM, IT, and the barriers and challenges that impede a successful blockchain's adoption and implementation.

\section{The Idea behind the Technology}

The ongoing "digital revolution" has changed many aspects of everyday life in recent decades (Fenwick \& Vermeulen, 2019). According to Klaus Schwab, "we are in the midst of the Fourth Industrial
Revolution, which will affect governments, businesses and economies in very substantial ways. We should not underestimate the change ahead of us" (Schwab, 2015). The Organisation for Economic Cooperation and Development (OECD) captures the obstacle that faces both individuals and organisations these days. We all need to "go digital." Clearly, emerging technologies are creating huge opportunities. But, the current change's speed and scale means that we often struggle to understand and adapt. It is challenging to learn what to do while working under conditions of cognitive uncertainty about the meaning and consequences of the technological rapid change. In fact, three technologies are poised to change supply chain business processes: robotic process automation (RPA), artificial intelligence (AI), and blockchain (Hartley \& Sawaya, 2019). Technology simplifies contact among stakeholders; and gradually replaces human to human interactions with interactions between human and machine. Such disruptions to accepted norms require a change in the way we coordinate activities inside and through organisations (Van Rijmenam, 2019).

Blockchain technology has the potency to bring benefits to governments and societies and can represent the next step in the egovernment development, as it enables reduced costs and complexity, shared trusted processes and ensured trusted recordkeeping (Olnes, Ubacht \& Janssen, 2017). In addition, blockchain technology as a digital enabler for the sustainable infrastructure focuses on three key points: the financing of infrastructure initiatives, the creation of visibility and alignment of climate action, and the provisioning of awareness and access for institutions and consumers (OECD, 2019). Thus, this study will be conducted to improve the current system in a way that fills the gaps in it and ensures to get the benefits of blockchain in line with the Kingdom's digital transformation. 


\section{Blockchain Definition and Characteristics}

Although an accepted definition of blockchain has not been agreed upon, according to Seebacher and Schuritz (2017, p. 3), "a blockchain is a distributed database, which is shared among and agreed upon a peer-to-peer network. It consists of a linked sequence of blocks, holding timestamped transactions that are secured by public-key cryptography and verified by the network community. Once an element is appended to the blockchain, it cannot be altered, turning a blockchain into an immutable record of past activities".

Blockchain technology varies from most information systems by including four key characteristics: non-localisation (decentralisation), security, auditability, and smart execution (Saberi et al. 2019). Indeed, the underlying information technology architecture and its 'unbreakable' data chain which is provided for secure and open transactions is the key promise of the blockchain (Randall, Goel \& Abujamra, 2017).

Through reducing the need for multiple intermediaries, blockchain can simplify supply chains by eliminating some transaction costs (Montecchi, Plangger \& Etter, 2019). Additionally, blockchain, inmemory computing, data leaks etc. can contribute to increasing data availability at the point of use (Pflaum et al. 2018b).

\section{Blockchain Evolution}

Leslie Lamport created the core ideas behind blockchain technology in the late 1980s and early 1990s (Dylan Yaga \& Scarfone, 2018 cited in; Leslie, 1998). After that, in 2008, Satoshi Nakamoto developed a digital ledger technology as the basis for the digital cryptocurrency known as Bitcoin. Cryptocurrencies like Bitcoin, Litecoin, and Ethereum are the foundations of the blockchain. They function in a distributed ledger to track transactions (Alhadhrami et al. 2017; Sadiku, Eze \& Musa, 2018).

The detailed technical foundations of the blockchain technology are outside the scope of this research. However, it is essential to shed the light on some blockchain concepts, features and terminology to enable understanding how blockchain is applied to solve healthcare problems. Technically, blockchain refers to either a distributed data infrastructure or a method for recording data using a crypto-analytic hash function (Wang, Y., Han \& Beynon-Davies, 2019). An important element of the technique that maintains the blockchain's strength is hashing (Dylan Yaga \& Scarfone, 2018). The new block's hash contains the previous block's hash. This makes falsifying new or existing parts of the blockchain extremely difficult, as the hash of a previous block determines the hash of future blocks. In order to change one block, the whole blockchain should be rewritten (White, 2017).

Today, many sectors have introduced blockchain technology for using its benefits in their respective fields (Gupte, Gupta \& Sinha, 2019). Therefore, in recent years, blockchain technology has gained significant popularity in various fields, including the healthcare industry (Angraal, Krumholz \& Schulz, 2017). While (IoT) technologies like RFID, low-power wide area networks (LPWA), wireless sensor networks (WSN), cyber-physical systems (CPS) etc. enable the vertical integration of information and material flows in supply chains, blockchain technology gains importance as far as the horizontal integration of information systems between companies is concerned (Pflaum et al. 2018a). In addition, while RFID tags can be cloned, blockchain technology is used through the supply chain to find the ownership details of each product (Soundarya, Pandey \& Dhanalakshmi, 2018). Furthermore, RFID tags allow product tracking, but the implementation of a new blockchain technology automatically makes tracking accessible to each network stakeholder (Kurki, 2016).

Although the benefits of blockchain such as integrity-protected data storage and process transparency (Wüst \& Gervais, 2018) are obvious, there are concerns about the efficacy and efficiency, which emerge with any new technology as well as its application (Randall, Goel \& Abujamra 
2017). Despite blockchain's potential to improve all kinds of supply chains, the literature about blockchain technology in the SCM field is in its infancy (Queiroz, Telles \& Bonilla, 2019).

\section{Blockchain Types}

There are two types of blockchain (BC): public and private. Public BCs are cryptocurrencies such as Bitcoin, enabling peer-to-peer transactions. Private BCs use BC-based platforms such as Ethereum or Blockchain-as-a-service (BaaS), running on a private cloud infrastructure. A private $\mathrm{BC}$ is an intranet, while a public $B C$ is the Internet (Sadiku, Eze \& Musa, 2018). Although the technology of BC was originally intended to be truly public and distributed (i.e. public blockchain), private BCs have also been developed. Private BCs are controlled by one or more entities. Otherwise, public and private BCs do not differ from one another (Kurki, 2016).

\section{Blockchain Technology in Pharmaceutical Supply Chain}

Blockchain's decentralised form is more trustworthy, transparent, and traceable within business processes, whereby all the transactions are constant, saved, immutable, and distributed among all network nodes (Sinclair, Shahriar \& Zhang, 2019). In fact, both scientists and business representatives are considering the possibility of adopting the basic idea of Bitcoin technology in the context of supply chain management because of the disruptive role of blockchain in financial applications (Pflaum et al. 2018b).

Operating costs in the health sector must be reduced more than ever, as patients' care and safety are improved (Bevilacqua et al. 2013). Safe, secure and scalable (SSS) data sharing in the field of healthcare is extremely important for successful decision-making (Siyal et al. 2019). Pharmaceutical supply chains are very different from typical supply chains, starting with the extraction of the raw materials, then a few production phases, continuing with shipping to stores, and selling to end customers (Kurki, 2016). This is because any disagreement in the healthcare supply chain might affect patients' wellbeing (Clauson et al. 2018).

Samuga (2020), in his paper entitled "how emerging technologies, like blockchain, could add further value" states that, one promising solution to address the formidable challenges within the pharmaceutical supply chain will be blockchain. He also argues that blockchain provides traceability in the product's lifecycles by relating data, propagating it and sending it through an organisation. This is important for highly regulated industries such as pharmaceuticals. In addition, The FDA and IBM believe that blockchain technology can support the exchange of data from multiple sources under agreed terms and for the purposes approved by the patient (Kshetri, 2018b).

Medicines move through a supply chain with several key players such as manufacturers, wholesalers and retailers, who participate in the production, transportation, distribution, and sale of these products (Bryatov \& Borodinov, 2019). The World Health Organisation (WHO) states that "global supply chains require a global system that can quickly alert people worldwide to the danger posed by substandard and falsified medical products" (WHO, 2017, p. 1). WHO estimates that 50 percent of the drugs consumed in the developing countries are counterfeit (Niforos, 2017). As counterfeit medicines have become one of the world's most complicated and challenging issues (Evans, 2018), blockchain allows the tracking of medicines at every point of the supply chain (Clark \& Burstall, 2018).

Previous studies have also focused on the safety of medicine distribution, lack of drugs, matching medicines' prices in the market, and accessibility to the standard recorded temperature, which are summarised in Table 2.1. In fact, blockchain may be an ideal technology to improve performance and reduce the risk of the above-mentioned issues (Kurki, 2016; Siyal et al. 2019). However, there is a lack of studies regarding the influence of blockchain on the sustainability of the 
pharmaceutical supply chain. Therefore, considering this research gap and the overall scarcity of blockchain research, this study explores the role of blockchain in pharmaceutical supply chain sustainability.

Shaker ALHARTHI, Paul R. CEROTTI and Shaghayegh MALEKI FAR (2020), Journal of Supply Chain and Customer Relationship Management, DOI: 10.5171/2020.562376 
Table 2.1: Summary of previous studies about using blockchain in pharmaceutical supply chain.

\begin{tabular}{|c|c|c|c|}
\hline Author (S) & problems & context & Solution using blockchain \\
\hline $\begin{array}{l}\text { (Bryatov \& } \\
\text { Borodinov, } \\
\text { 2019) }\end{array}$ & $\begin{array}{l}\text { Counterfeit } \\
\text { Drug }\end{array}$ & Russia & $\begin{array}{l}\text { Information regarding the identity of drugs being manufactured within the plant and their movements } \\
\text { seen throughout the supply chain in blockchain would assist to clearly and accurately verify the } \\
\text { authenticity of the pharmaceutical products which reach the shelves of pharmacies. }\end{array}$ \\
\hline (El-Din, 2019) & $\begin{array}{l}\text { Matching } \\
\text { medicines } \\
\text { prices, lack of } \\
\text { drugs }\end{array}$ & Egypt & $\begin{array}{l}\text { BC can be utilised to overcome the issue of undercurrents prevalent in Egypt. The issue causes a large } \\
\text { number of child deaths as a direct result of the inadequacy of milk cans. A large number of elderly } \\
\text { people die as a result of chronic illness due to the inadequacy of medication and other import-related } \\
\text { issues. }\end{array}$ \\
\hline $\begin{array}{l}\text { Erdenebold, } \\
\text { Rho and Hwang } \\
\text { (2019) }\end{array}$ & $\begin{array}{l}\text { Counterfeit } \\
\text { Drug }\end{array}$ & Worldwide & $\begin{array}{l}\text { The sole focus and purpose of blockchain is to verify the origin of the drug, offer transparency, regulate } \\
\text { medication history, ensure drug security, enhance interoperability performance, offer protection from } \\
\text { falsification and be financially effective by preventing any losses within the supply chain. This has the } \\
\text { potential to prevent thousands of deaths. It financially benefits both drug manufacturers as well as } \\
\text { consumers. }\end{array}$ \\
\hline $\begin{array}{l}\text { Jamil et al. } \\
\text { (2019) }\end{array}$ & $\begin{array}{l}\text { Counterfeit } \\
\text { Drug }\end{array}$ & Worldwide & $\begin{array}{l}\text { BC has proven that it has the capacity to alter the existing traditional lines of supply to become more } \\
\text { transparent, secure, digital, decentralised, audible and continuous. The use of blockchain technology } \\
\text { improves performance with regards to throughput, whilst simultaneously reducing the system latency } \\
\text { by the use of minimal resources. }\end{array}$ \\
\hline $\begin{array}{l}\text { Kumar, A et al. } \\
\text { (2019) }\end{array}$ & $\begin{array}{l}\text { Counterfeit } \\
\text { Drug }\end{array}$ & India & $\begin{array}{l}\text { The primary advantage of BC-based supply chain network is the transparency seen during } \\
\text { transactions, the ability to track drugs via auditing and the ability to recognise any attempts made to } \\
\text { alter data. }\end{array}$ \\
\hline $\begin{array}{l}\text { (Menezes et al. } \\
\text { 2019) }\end{array}$ & $\begin{array}{l}\text { Safety of } \\
\text { medicine } \\
\text { distribution }\end{array}$ & Worldwide & $\begin{array}{l}\text { There is a decentralised system in place in BC which assists to measure temperature and levels of } \\
\text { humidity during the process of transportation as well as at sites of manufacturing through the use of } \\
\text { sensors. }\end{array}$ \\
\hline $\begin{array}{l}\text { Nayyar et al. } \\
(2019)\end{array}$ & $\begin{array}{l}\text { Falsified and } \\
\text { substandard } \\
\text { drugs }\end{array}$ & USA & $\begin{array}{l}\mathrm{BC} \text { guarantees data provenance with regards to the supply chain and is useful in the detection of the } \\
\text { inclusion of any fake mediation. }\end{array}$ \\
\hline $\begin{array}{l}\text { Pashkov and } \\
\text { Soloviov (2019) }\end{array}$ & $\begin{array}{l}\text { Counterfeit } \\
\text { Drug }\end{array}$ & Europe & $\begin{array}{l}\text { Integration of BC in pharmacy would offer you comprehensive legal cover for the tracking and supply } \\
\text { of medication. It would also guarantee the transparency of the deliveries made to you whilst } \\
\text { simultaneously minimizing the logistical expenses. }\end{array}$ \\
\hline
\end{tabular}

Shaker ALHARTHI, Paul R. CEROTTI and Shaghayegh MALEKI FAR (2020), Journal of Supply Chain and Customer Relationship Management, DOI: $10.5171 / 2020.562376$ 


\begin{tabular}{|c|c|c|c|}
\hline Author (S) & problems & context & Solution using blockchain \\
\hline & $\begin{array}{l}\text { Operational } \\
\text { costs }\end{array}$ & & \\
\hline $\begin{array}{l}\text { Raj, Rai and } \\
\text { Agarwal (2019) }\end{array}$ & $\begin{array}{l}\text { Counterfeit } \\
\text { Drug }\end{array}$ & Worldwide & $\begin{array}{l}\text { BC assists to develop a system which is both transparent and traceable. It permits real time monitoring } \\
\text { of goods for the logistic companies. It also assists to present ownership proof where only the } \\
\text { respective ownership parties can handover their authority to another party. }\end{array}$ \\
\hline Shrikant (2019) & $\begin{array}{l}\text { Counterfeit } \\
\text { Drug }\end{array}$ & India & $\begin{array}{l}\text { BC assists to keep track of medication from the point of manufacturing till it is been administered to a } \\
\text { patient. Following the administration of the drug, it would asses the impact made on the patient on a } \\
\text { database for future reference. }\end{array}$ \\
\hline $\begin{array}{l}\text { Zhang et al. } \\
\text { (2019) }\end{array}$ & $\begin{array}{l}\text { Temperature } \\
\text { records }\end{array}$ & USA & $\begin{array}{l}\text { BC assists to minimise the latency between temperature assessment and implementation of corrective } \\
\text { actions within internal processes. }\end{array}$ \\
\hline $\begin{array}{l}\text { (Alzahrani \& } \\
\text { Bulusu, 2018) }\end{array}$ & $\begin{array}{l}\text { Counterfeit } \\
\text { Drug }\end{array}$ & Worldwide & $\begin{array}{l}\text { BC poses the ability to monitor and accurately locate products and identify any potential attempts of } \\
\text { altering, cloning or tag recycling. }\end{array}$ \\
\hline $\begin{array}{l}\text { Boulos, Wilson } \\
\text { and Clauson } \\
(2018)\end{array}$ & $\begin{array}{l}\text { Counterfeit } \\
\text { Drug }\end{array}$ & USA & $\begin{array}{l}\text { Integration of } \mathrm{BC} \text { assists to oversee the raw materials utilized for the manufacture and recognise } \\
\text { materials which are of sub-par quality or any falsified medication. }\end{array}$ \\
\hline $\begin{array}{l}\text { Chavali et al. } \\
\text { (2018) }\end{array}$ & $\begin{array}{l}\text { Counterfeit } \\
\text { Drug }\end{array}$ & Worldwide & $\begin{array}{l}\text { BC platform guarantees the verification of drug detection and notification. It builds up rapport and } \\
\text { transparency amongst all the concerned parties involved with the alteration of ownership within the } \\
\text { supply chain. BC has the potential to offer a solution to counterfeit drug issue. It permits the recording } \\
\text { of genomic data which can be utilized as a tool for fighting fake drugs and safeguard the intellectual } \\
\text { property rights. }\end{array}$ \\
\hline $\begin{array}{l}\text { Clark and } \\
\text { Burstall (2018) }\end{array}$ & $\begin{array}{l}\text { Counterfeit } \\
\text { Drug }\end{array}$ & Worldwide & $\begin{array}{l}\text { BC possesses the capabilities to completely alter the currently enforced methodologies which are set } \\
\text { by pharmaceutical companies for anti-counterfeiting and enforcement. It also has the ability to interact } \\
\text { and offer knowledge to the customer regarding hazards of counterfeit drugs, whilst offering them the } \\
\text { ability to authenticate the genuineness of the products that they've purchased. }\end{array}$ \\
\hline Evans (2018) & $\begin{array}{l}\text { Counterfeit } \\
\text { Drug }\end{array}$ & USA & $\begin{array}{l}\text { BC guarantees the safety and highlights any possible safety hazards which are in place for supply } \\
\text { chains. It assists in developing consumer confidence. Integration of BC permits companies to prevent } \\
\text { consumers from purchasing counterfeit drugs by notifying them of such cases. }\end{array}$ \\
\hline $\begin{array}{l}\text { Haq and Esuka } \\
\text { (2018) }\end{array}$ & $\begin{array}{l}\text { Counterfeit } \\
\text { Drug }\end{array}$ & Worldwide & $\begin{array}{l}\text { BC is an ideal platform to enhance trust in a world where it is scarce, it ensures accurate tracking of a } \\
\text { product during the course of its supply chain. }\end{array}$ \\
\hline
\end{tabular}

Shaker ALHARTHI, Paul R. CEROTTI and Shaghayegh MALEKI FAR (2020), Journal of Supply Chain and Customer Relationship Management, DOI: $10.5171 / 2020.562376$ 


\begin{tabular}{|c|c|c|c|}
\hline Author (S) & problems & context & Solution using blockchain \\
\hline $\begin{array}{l}\text { (Jochumsen \& } \\
\text { Chaudhuri, } \\
\text { 2018) }\end{array}$ & $\begin{array}{l}\text { Counterfeit } \\
\text { Drug }\end{array}$ & USA & $\begin{array}{l}\text { BC also has the ability to track and trace which cannot be done with IoT equipment. BC can track a } \\
\text { product at all stages of the supply chain which would ensure comprehensive coverage throughout its } \\
\text { lifecycle. }\end{array}$ \\
\hline $\begin{array}{l}\text { (Katuwal et al. } \\
\text { 2018) }\end{array}$ & $\begin{array}{l}\text { Counterfeit } \\
\text { Drug }\end{array}$ & Worldwide & $\begin{array}{l}\text { BC provides information of integrity of data and provenance which can be utilized to offer effective } \\
\text { countermeasures against drug counterfeiting. }\end{array}$ \\
\hline $\begin{array}{l}\text { Soundarya, K, } \\
\text { Pandey and } \\
\text { Dhanalakshmi } \\
\text { (2018) }\end{array}$ & $\begin{array}{l}\text { Counterfeit } \\
\text { Drug }\end{array}$ & Worldwide & $\begin{array}{l}\text { BC can be utilized during all stages of the supply chain to ensure ownership details for individual } \\
\text { products. Hence, in a scenario where RFID tags are cloned, product ownership cannot be changed. BC } \\
\text { cannot be altered; it is transparent and ensure complete protection which prevents any wrongdoings } \\
\text { within the supply chain. }\end{array}$ \\
\hline $\begin{array}{l}\text { Plotnikov and } \\
\text { Kuznetsova } \\
(2018)\end{array}$ & $\begin{array}{l}\text { Counterfeit } \\
\text { Drug }\end{array}$ & Russia & $\begin{array}{l}\text { BC guarantees that information remains unchanged. It prevents the sale of counterfeit or substandard } \\
\text { drugs through the comprehensive regulation of all steps of the product cycle which consists of } \\
\text { production, logistics and distribution. }\end{array}$ \\
\hline $\begin{array}{l}\text { Radanović and } \\
\text { Likić (2018) }\end{array}$ & $\begin{array}{l}\text { Counterfeit } \\
\text { Drug }\end{array}$ & Worldwide & $\begin{array}{l}\text { BC is a tool for monitoring the movement of pharmaceutical agents through the supply chain along } \\
\text { with its verification. The products could be given unique codes, which would then be verified through } \\
\text { blockchain to ensure its authenticity. This would be of immense assistance in fighting against the } \\
\text { abundance of counterfeit medication. }\end{array}$ \\
\hline $\begin{array}{l}\text { Scott et al. } \\
(2018)\end{array}$ & $\begin{array}{l}\text { Counterfeit } \\
\text { Drug } \\
\text { Contamination } \\
\text { of medicines }\end{array}$ & USA & $\begin{array}{l}\text { Provision of pharmaceutical traceability throughout the course of the supply chain is an ideal scenario } \\
\text { for the inclusion of BC. }\end{array}$ \\
\hline
\end{tabular}

Shaker ALHARTHI, Paul R. CEROTTI and Shaghayegh MALEKI FAR (2020), Journal of Supply Chain and Customer Relationship Management, DOI: $10.5171 / 2020.562376$ 


\section{Blockchain and Sustainable Supply Chain}

Supply chain management (SCM) plays a variety of vital roles in different sectors or industries (Elango, 2018). Thus, the benefits of integrating SC with blockchain are increased sustainability; decreased errors and delays, reduced transportation costs, faster issue identification, increased consumer and partner trust, and improved product transportation process and inventory management (Tijan et al. 2019). Blockchain technology as a distributed, immutable, transparent, and trustworthy databases shared by a community can also affect the sustainable supply chain networks (Saberi et al. 2019). Blockchain can be a useful tool in tackling certain sustainable development issues (see Table 2.2) (Lund et al. 2019).

Triple bottom line (TBL) sustainability has three major areas which focus primarily on the interplay and overlap of the social, environmental and economic factors (Brandenburg et al. 2014). The economic dimension refers to raising the living standard and economic well-being (Abdullah et al. 2018). The supply chain faces significant challenges in the economic area of sustainability including procurement contracts, insurance claims, increased financial transaction costs, sustainability monitoring costs, and investment (Chandan, Potdar \& Rosano,
2019). Therefore, firms and their supply chains are likely to obtain benefits from blockchain technology adoption and also from several business aspects that influence their economic performances.

The environmental dimension relates to the practices that do not influence future generations' environmental resources (Alhaddi, 2015). Sustainability can be improved throughout the SC by sharing information that will help in resource planning and policy-making, which in turn can lead to a decrease in the consumption of natural resources (Kouhizadeh \& Sarkis, 2018). Therefore, blockchain technology can contribute to the environmental aspect of supply chain sustainability. The social dimension refers to the empowerment of groups previously considered as minorities, diversity and inclusion, as well as a society with a healthy lifestyle (De Carvalho, 2018). The stabilisation and immutability of information is one way to build SC's social sustainability (Saberi et al. 2019). However, there are few studies that are discussing the social issues (Brandenburg et al. 2014; Galal \& Moneim, 2016; Rajeev et al. 2017). Moreover, there is no clear evidence at this time that illustrates the impact of the use of IT applications on the social aspect of supply chain sustainability (Fiorini \& Jabbour, 2017; Thöni \& Tjoa, 2017). Thus, researchers should attempt to explain how value is created, captured and distributed in a blockchain-enabled social supply chain (Wang, Y., Han \& Beynon-Davies, 2019). 
Table 2.2: Current issues in the supply chain concerning sustainability dimensions and how blockchain can solve these issues.

\begin{tabular}{|l|l|}
\hline Sustainability issues & \\
\hline Economic issues & $\begin{array}{l}\text {-BC permits disintermediation of the SC where reduced tiers assist to minimise the cost of time and transaction whilst reducing the } \\
\text { business waste produced (Saberi et al. 2019). } \\
\text {-Implementation of BC permits the use of advanced payment modalities such as cryptocurrency and tokens (Kouhizadeh \& Sarkis, } \\
2018) . \\
\text {-BC assists to lower latency, errors of communication and fraud while completely excluding the effects of third party oversight (Ally \& } \\
\text { Wark, 2019). }\end{array}$ \\
\hline Environmental \\
issues & $\begin{array}{l}\text {-BC is capable of tracking substandard products. It also assists to recognise additional transactions which would occur with the } \\
\text { product, minimising the effort needed for reworking and recalling products (Saberi et al. 2019). } \\
\text {-BC enhances the transparency and the traceability of SC culminating in increased sustainability of the environment (Chandan, Potdar } \\
\text { \& Rosano, 2019). } \\
\text {-BC has the ability to assess and control the release of gases which brings about climate change by effectively recording emissions and } \\
\text { comparing it against restrictions and limitations which are in place (Sulkowski, 2018). }\end{array}$ \\
\hline Social issues & $\begin{array}{l}-\mathrm{BC} \text { permits the different stakeholders of the supply chain to be more open, trustworthy, reliable and secure regarding SC. This could } \\
\text { later on develop to bring about social sustainability (Chandan, Potdar \& Rosano, 2019). } \\
-\mathrm{BC} \text { assists customers to be secure and comfortable in consuming the products that they purchase as they are aware of the flow of the } \\
\text { product throughout its different stages (Parung, 2019). } \\
\text {-BC assists governments to obtain information on work hours of the employees through blockchain networks, in order to assess the } \\
\text { adherence of companies to suitable workhours and monitor violations of overtime restrictions. It also can be used to assess if the } \\
\text { employees are paid in a timely manner for their services (Venkatesh et al. 2020). }\end{array}$ \\
\hline
\end{tabular}




\section{Benefits and Challenges of Blockchain Implementation}

The implementation of blockchain technology systems has numerous benefits (Mezquita, 2019; Wamba \& Queiroz, 2020; Zheng et al. 2018):

Firstly, the most evident and popular feature of blockchain is that it eradicates the need for a centralised trusted third party in distributed applications; in other words, it allows two or more parties to conduct transactions without a centralised authority in a distributed environment (Agbo, Mahmoud \& Eklund, 2019). In addition, blockchain technology is useful in cases where there are multiple administrative authorities and those parties have a lack of trust. If the collaborative parties have a trust deficit, they usually select a trusted third party. However, finding this third party sometimes presents challenges or risks. A typical example could be a supply chain management system in which several parties work together to deliver goods. Another example may be a consortium of independent companies involved in a government project, where the parties are facing a deficit of confidence (Chowdhury et al. 2018).

Secondly, data interoperability and security are the main benefits of blockchain deployment in healthcare. Interoperability of healthcare allows the sharing and use of information among two or more systems (Sadiku, Eze \& Musa, 2018). This greater interoperability could lead to better access to medical records and drug databases, so blockchain technology could significantly improve medical services (Heston, 2017).

Thirdly, on a system such as pharmaceutical SCM, another reason to use blockchain technology is its security. Blockchain is the best option to provide cybersecurity for the $21^{\text {st }}$ century, and until now, no breaches have been identified (Haq \& Esuka, 2018).

Fourthly, instead of a central authority who keeps everything in sync and dictates the database's modification history, each participant has a say in what he thinks the true course of events has been. It is a new way to organise and manage databases in a leaderless democracy of devices, algorithmically incentivised to work together for one shared consensus view (Mattila, Seppälä \& Holmström, 2016). Being decentralised promotes security by eliminating any exploitable single targets (Sinclair, Shahriar \& Zhang, 2019).

Although blockchain has numerous benefits that can help organisations achieve their goals, the implementation of blockchain faces many challenges (He et al. 2018; Namasudra et al. 2020; Tasatanattakool \& Techapanupreeda, 2018):

Firstly, due to the nature of blockchain, data stored or transferred out of the chain is not securely confidential (Alhadhrami et al. 2017). Since transactions are public, traceable clues may still be used to disclose users' identities and personal information (Gao, Hatcher \& Yu, 2018).

Secondly, blockchain implementation consists of bringing together all the relevant parties, which can, in many cases, be a difficult undertaking (Kshetri, 2018a). Participants need to agree on the terms of a transaction or a contract. This requirement will be one of the biggest barriers in the coming few years to the broader implementation of blockchain applications. Once the rules are in place, blockchain systems could automate many sustainability processes that professionals struggle to manage manually, allowing them to run much more efficiently (Clancy, 2017).

Thirdly, blockchain provides constant data integrity. The clear drawback of this is that, as the number of transactions continues to grow, blockchain size will increase accordingly (Gao, Hatcher \& Yu, 2018). The consequence of this continuous growth is not only higher storage costs, but also the decrease in blockchain distribution speed over the network. In addition, scalability is a difficult issue and must be taken into consideration in the design of blockchain applications (Gao, Hatcher \& Yu, 2018).

Fourthly, not all countries are ready to participate in blockchain-based solutions 
due to the need for a high level of computerisation. Many supply chain partners in developing and least developed countries are often not willing to embrace blockchain. Without their involvement, the full potential of blockchain in the supply chain is difficult to realise (Kshetri, 2018a). However, KSA has made a great progress in implementing blockchain in different ministries such as the Saudi Arabian Monetary Authority (SAMA), Customs and Municipalities. These achievements demonstrate that the Kingdom is in the midst of implementing the blockchain technology. The Kingdom of Saudi Arabia's implementation of blockchain technology is considered as an important development because it supports its goals to become a digital country, and this transforming technology naturally integrates with the Saudi's vision for 2030 (Saudi Press Agency, 2018).

Modern applications of blockchain have to adapt to certain technical challenges and drawbacks that blockchain technology requires. For example, security, privacy, throughput, size and bandwidth, performance, usability, data integrity and scalability are just some of the attributes required to implement blockchain in high quality (Koteska, Karafiloski \& Mishev, 2017).

\section{Overview of Sustainability and Supply Chain Management}

For the past decade, sustainability and supply chain management have been of great interest to academia and practitioners (Ghadimi, Wang \& Lim, 2019; Lin, Tseng \& Pai, 2018; Rasool, Ahmad \& Nazam, 2016). While various research efforts have been dedicated to evaluate the sustainability of supply chains, few have taken into account all the three dimensions of sustainability (Galal \& Moneim, 2016). In fact, integrating sustainability into the supply chain practices plays an important role in ensuring that certain social, economic and environmental benefits are achieved (Mani, Gunasekaran \& Delgado, 2018). Yamoah (2019) states that integrating sustainability in supply chain management is surely not the end, but rather an endless journey characterised by a path of progress as a result of the dynamic, radical and emerging nature of the issues. Thus, an overview has been described in the following sections.

\section{Sustainability}

Sustainability has three main pillars, namely: environment, economy and society (Sidhu, 2020). Collectively, these three sustainability elements are called "triple bottom line" or 3BL (Wang, X., Lin \& Tian, 2019). The environmental dimension refers to the involvement in practices that will not compromise future generations' environmental resources (Alhaddi, 2015). The social aspect relates to empowering minority groups, diversity and inclusion, and a healthy social living (De Carvalho, 2018). The economic aspect refers to improving living standards and the economic well-being (Abdullah et al. 2018).

Nowadays, businesses are paying increased attention to sustainability issues (Ahi \& Searcy, 2013; Bellucci, Bini \& Giunta, 2020). A major challenge for an organisation, however, is to integrate and balance the three sustainability aspects in a responsible manner that maintains financial stability and competitiveness while incorporating ecological and social demands (Abdullah et al. 2018).

\section{Supply Chain Management}

Various definitions of SCM exist due to an interdisciplinary approach (Kaur, Singh \& Singh, 2020). SCM identifies all the activities involved in the production and delivery of a product from raw materials to the end consumer (Lummus \& Vokurka, 1999; Mathur et al. 2018). These activities are: manufacturing and assembly, warehousing and inventory tracking, order placing and order management, supplier management, distribution across all systems, delivery to the end consumer, and the information systems required to monitor all of these activities (Cox, Blackstone Jr \& Spencer, 1992; Nguyen et al. 2019). In addition, a research by (Baah \& Jin, 2019) describes SCM as materials and services flow, supply chain partners collaboration, and sharing of information. Therefore, information sharing 
is a well-advocated way of improving SC efficiency (Choi, Wallace \& Wang, 2016).

The trends of SCM such as business markets globalisation, shorter product life cycles, digitalisation, and multi-faceted customer expectations, along with innovations such as resources scarcity, more restrictive regulatory requirements, and a longer-term emphasis, have led to the development of highly complex supply chains (Saeed \& Kersten, 2019). In fact, the effective development and management of supply chain networks help businesses cut costs and enhance customer value (Christopher, 2016). Indeed, the main objective of SCM is to improve organisational effectiveness and efficiency (Alzawawi, 2014; Li et al. 2006). As a result, several studies emphasise SCM's criticality as a mean to ensure organisational success (Childerhouse \& Towill, 2003; Habib, 2017).

\section{Sustainable Effort in Supply Chain Management}

Sustainable supply chain management (SSCM) has attracted considerable interest among academics and practitioners over the past decade (Azadi et al. 2015). According to Dubey et al. (2017), there is a growing body of SSCM-related literature. SSCM can be defined as the planning, managing, regulating and organising of a supply chain to make it truly sustainable while ensuring that there is no harm to economic, environmental and social systems over a longer period of time (Pagell \& Shevchenko, 2014). In fact, SSCM is the expansion of the traditional concept of the supply chain, by adding social, economic and environmental elements of sustainability (Wittstruck \& Teuteberg, 2012).

SCM has long been associated with the sustainability discourse. In the supply and value chain sector, an evolving point of view is that "a company is no more sustainable than its supply chains" (Krause, Vachon \& Klassen, 2009, p. 19). SSCM is perceived to be the emergence of a new era that combines environmental performance, social efficiency, and economic contribution (Ansari \& Kant, 2017). Therefore, the economic, environmental and social aspects of sustainability must be taken into account by a truly sustainable organisation (Ahmadi, Kusi-Sarpong \& Rezaei, 2017). Today, it is no longer enough for companies to be profit-oriented; businesses must reduce their negative environmental effects and be responsible for child labour, health, safety, and pollution (Özçelik \& Öztürk, 2014). Therefore, SSCM focuses on the environmental effects throughout the supply chain (Rasool, Ahmad \& Nazam, 2016).

SCM practices not only play a vital role in achieving business goals, but they also have the potential to tackle sustainability concerns (Cousins et al. 2019). The SCM's strategic role and its potential for significantly contributing to the sustainable development are evident from the academic research on the topic (Jadhav, Orr \& Malik, 2019; Touboulic \& Walker, 2015). However, there is a limited number of studies on the sustainable development in developing countries (Eitiveni, Kurnia \& Buyya, 2017; Khuntia et al. 2018). Hence, to address this gap in the literature, the current research will be conducted.

\section{Supply Chain Effectiveness}

Supply chain efficiency expresses an evaluation of its performance, and thus it is a measure of the efficacy of its specific action (Jacyna-Gołda et al. 2018). In addition, The effectiveness addresses how much a company can meet its predetermined goals (Azadi et al. 2015). Supply chain effectiveness consists of an operational and social performance that significantly and positively affects the financial performance (Akhtar \& Khan, 2015). Kumar, S, Liu and Demirag (2016) argue that cultural factors play an important role in influencing the effectiveness of organisations. Furthermore, Kanda and Iravo (2015) in their study, indicate that procurement processes, IT infrastructure, distribution channels and competency of medical staff in the supply chain, are factors affecting the efficiency of the supply chain of pharmaceutical products. Thus, one of the most important factors to maximise the efficiency of all the key players in any supply 
chain is the adoption of appropriate IT tools in the SC (Dehgani \& Navimipour, 2019).

\section{Pharmaceutical Supply Chain}

The current pharmaceutical supply chain system is complex (Katuwal et al. 2018; Schöner et al. 2017; Suhail, Pandey \& Hong, 2019) and outdated (Haq \& Esuka, 2018; Shrikant, 2019); it does not allow producers and regulatory authorities' visibility and influence over the delivery of drugs, and it cannot overcome the challenge of cybersecurity in the $21^{\text {st }}$ century (Shrikant, 2019). In addition, many health systems and hospitals have difficulties in achieving a high level of service as they have not addressed how to manage, supply, and use medicines to save lives and improve health (Nabelsi \& Gagnon, 2017; Uthayakumar \& Priyan, 2013).

A strategic feature of any health system is the access to medicines (Kapoor, Devesh, 2018). This feature depends on sustainable financing, comprehensive information systems, reliable supply systems and essentially on coordination and collaboration, either between internal supply chain partners or global supply chain partners (Benazzouz, Charkaoui \& Echchatbi, 2019). Therefore, An efficient system of supply management of medicines should be established to prevent drug shortage or waste in any health institution (Iqbal, Geer \& Dar, 2017). Hence, more studies are needed to improve the pharmaceutical supply chain system in developing regions (Privett \& Gonsalvez, 2014) such as KSA.

\section{Pharmaceutical sector in KSA}

The pharmaceutical sector in KSA is still in the phase of development (Alruthia et al. 2018; Alsaddique, 2017). It is important to have an efficient and transparent system whereby the pharmaceutical supply chain can maintain accurate records of its pharmaceutical supplies in terms of expiry dates and accessible quantities through a computerised program (Alruthia et al. 2018). Blockchain is one technology that improves the integrity, authenticity and coherence of medical records that have been preserved and shared (Alhadhrami et al. 2017). Furthermore, blockchain can be an effective solution when tracking a patient's health record or moving drugs through the supply chain (Sadiku, Eze \& Musa, 2018). Therefore, this study will explore the technology of blockchain in the pharmaceutical supply chain in the context of KSA.

\section{Theoretical Foundation of the Study and the Research Framework}

This section focuses on the theoretical foundation of the study. Moreover, based on an extensive review of the literature and theories, the proposed research framework has been depicted in this section.

\section{TOE framework}

The TOE framework (technology, organisation and environment) was developed by Tornatzky, Fleischer \& Chakrabarti (1990). This framework explores three aspects that affect the adoption and implementation process of technological innovations, namely technological, organisational, and environmental. These three aspects will assist the researcher to understand the adoption of blockchain in the health industry.

The technological context focuses on the perceived benefits, complexity and compatibility (Starbuck, 1976). The perceived benefit is the degree to which users believe that using a system would improve their performance (Davis, 1989). Complexity is the degree to which users believe that using the system is difficult (Sonnenwald, Maglaughlin \& Whitton, 2001). Compatibility is the degree to which a system is perceived as consistent with the values, past experience, and needs of an organisation (Rogers, 2010).

The organisational context focuses on the organisational readiness, top management support, and blockchain knowledge. Organisational readiness can be defined as the availability of resources to adopt a new technology (Alsheibani, Cheung \& Messom, 2018; Iacovou, Benbasat \& Dexter, 1995). 
Top management support can be defined as the degree to which top management support provides adequate resources for the adoption of a new technology (Useem, 1993). Blockchain knowledge is the degree to which managers know about a technology, which is a critical factor for adopting blockchain innovations (Clohessy, Acton \& Rogers, 2019).

The environmental aspects of an organisation are part of its business activities. It focuses on the regulatory environment and government support (Ijab et al. 2019; Tornatzky, Fleischer \& Chakrabarti, 1990). The regulatory environment can be defined as the degree to which the organisation/government policies affect the innovations (Hsu \& Lin, 2016). Government support can be defined as the degree to which a government regulates its policies to provide institutions with growth and development (Ayandibu \& Houghton, 2017).

TOE framework has been adopted in many studies in the context of blockchain (Clohessy, Acton \& Rogers, 2019). TOE has also been adopted by information technol gies in general. Table 2.3 shows some of the studies that have adopted the TOE.

Table 2.3: Examples of the studies that applied the TOE

\begin{tabular}{|l|l|l|}
\hline \multicolumn{1}{|c|}{ Context } & \multicolumn{1}{c|}{ Description } & \multicolumn{1}{c|}{ Reference } \\
\hline Cloud Computing & $\begin{array}{l}\text { Utilised the TOE to investigate the adoption of } \\
\text { cloud computing in higher education } \\
\text { institutions. }\end{array}$ & $\begin{array}{l}\text { (Henderson, Sheetz } \\
\text { \& Trinkle, 2012) }\end{array}$ \\
\hline $\begin{array}{l}\text { Enterprise } \\
\text { Resource Planning } \\
\text { (ERP) }\end{array}$ & $\begin{array}{l}\text { Investigated switching to cloud EPR in a } \\
\text { telecommunication company. }\end{array}$ & (Chang, 2020) \\
\hline Blockchain & $\begin{array}{l}\text { Investigated the adoption of blockchain in } \\
\text { SMEs. }\end{array}$ & (Wong et al. 2019) \\
\hline
\end{tabular}


TOE framework is earlier implemented in IT adoption studies because it proves itself as a useful analytical tool that can be employed in adopting and analysing multiple aspects of the adoption of blockchain in a selected organisation. It provides a strong theoretical base, future opportunities regarding innovation domains and a reliable experimental support. TOE framework would help to explore the technological, organisational and environmental aspects in terms of both the opportunities and challenges for technological innovations in the form of blockchain in the supply chain (Al-Hujran et al. 2018; Tornatzky, Fleischer \& Chakrabarti, 1990).

Based on the discussion above and the relevant literature, TOE is the most suitable model for this research (Wong et al. 2019). Thus, the TOE framework has been adopted for the development of the theoretical framework of this research. In order to increase the explanatory power of TOE, the author has modified TOE by incorporating some factors from another model, namely Technology Readiness Index (TRI) which has been developed by Parasuraman (2000). TRI will be discussed in the following section.

Technology Readiness Index Theory (TRI)

\section{The Research Framework}

The proposed theoretical framework has been developed through the consideration of the blockchain, supply chain, and the literature from the triple bottom line approach of sustainability in the supply chain with the support of TOE framework and some aspects from TRI theory (see Figure 1). From the wider literature review, it is important to consider sustainability for
TRI is a theory that has been developed by Parasuraman (2000), who found that the readiness of organisations/users plays an important role in the adoption of a new technology. He stated that users' readiness in adopting a new technology is determined by four factors: optimism, innovativeness, discomfort and insecurity. Optimism can be defined as the degree to which the users have confidence that technology will be useful in performing their tasks (Napitupulu et al. 2018). Innovativeness can be defined as the degree to which organisation members have the abilities to invent a new technology (Bettiga, Lamberti \& Lettieri, 2019). Discomfort which can be defined as the degree to which users perceive that they lack control over technology (Rinjany, 2020). Insecurity can be defined as the degree to which users do not trust the technology to be safe for transmitting information (Rinjany, 2020). It is worth mentioning that these aspects are used as moderators in the proposed model

TRI has been validated in several studies (Humbani \& Wiese, 2018; Meng, Elliott \& Hall, 2009; Westjohn et al. 2009). Parasuraman (2000), stated that the TRI is excellent at predicting the usage of technology-based services, such as blockchain, which is the focus of this study. Therefore, it is expected that TRI will provide valuable insights into this research.

SCM because sustainability is necessary in the case of environmental, social, and economic disruptions (Ansari \& Kant, 2017). There is a piece of evidence that the sustainable supply chain is essential for the survival and competitiveness of KSA institutions (Rehman et al. 2020); in such a situation, the proposed research model has been developed for the sustainability and effectiveness of the pharmaceutical supply chain of KSA. 


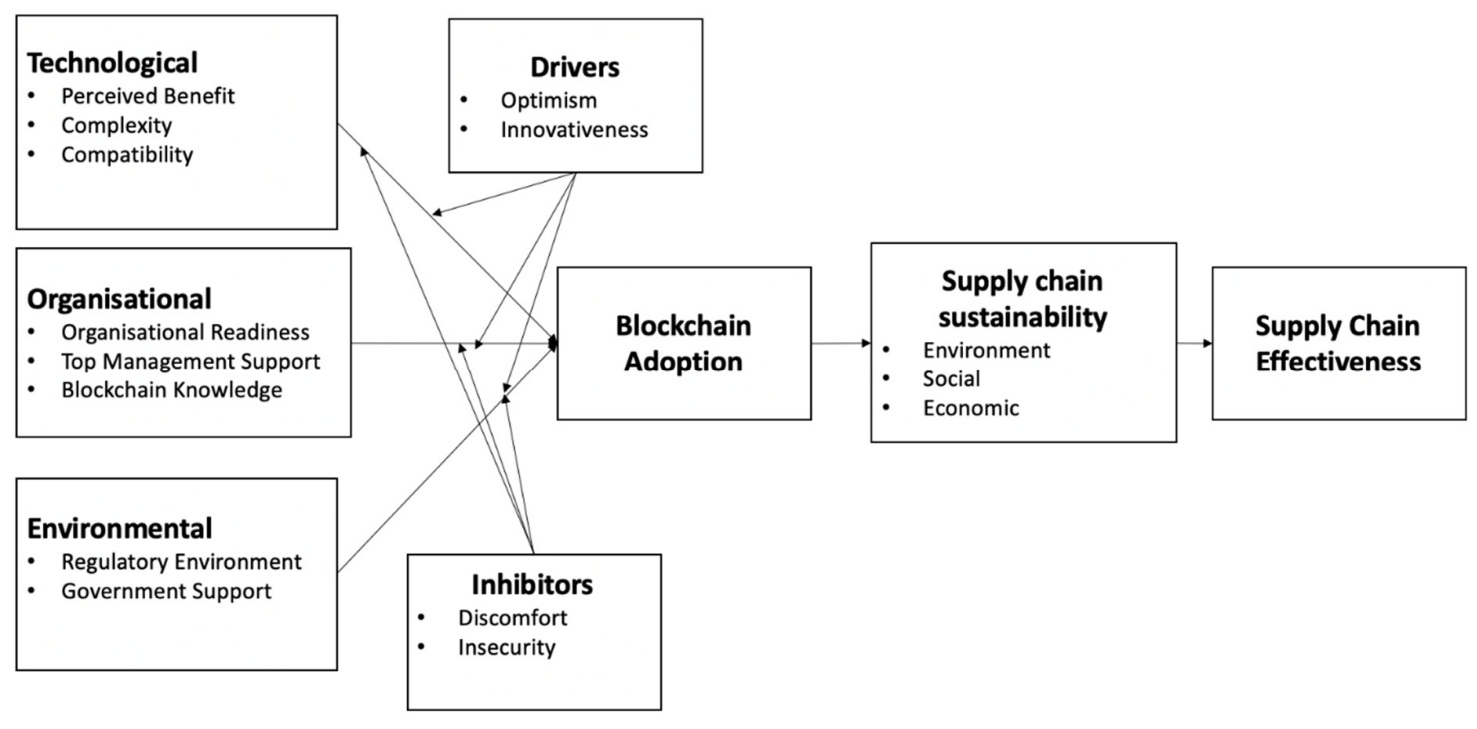

Figure 1: The proposed theoretical framework

According to the proposed theoretical framework of this study, the three aspects of the TOE framework namely, technological, organisational, and environmental aspects of an organisation may affect the adoption of blockchain. Consequently, the adoption of blockchain will affect the sustainability of the supply chain in the organisation which will result in its supply chain effectiveness. While the three aspects of the TOE framework affect the adoption of blockchain, the existence of other factors, such as drivers and inhibitors, may weaken this relationship.

\section{Expected Contributions of the Study}

The importance of the present study stems from its theoretical and practical importance according to the following:

\section{Theoretical Contributions}

Firstly, this study is among the initial few studies that investigate the blockchain technology in the pharmaceutical supply chain sustainability and effectiveness. The second theoretical contribution of this research is to explore the role of blockchain in contributing to sustainability efforts. By integrating variables from TOE, TRI, blockchain and supply chain, the study will provide a clear picture to better understand the influence of these factors on the sustainability of the supply chain, thus supply chain effectiveness. Third, this research will develop a guideline for blockchain implementation in the pharmaceutical supply chain in the context of Saudi Arabia, which hopefully will increase the uptake of blockchain in the pharmaceutical supply chain. The last theoretical contribution of this research is discovering and diagnosing the opportunities, barriers and challenges of blockchain adoption and implementation in the pharmaceutical supply chain in the context of KSA.

\section{Managerial Implications}

This study has important implications for managers, practitioners, consultants, and decision-makers to understand the use of advanced and modern techniques and approaches which may assist in creating a strong connection among healthcare players. It also may assist find strategies to enhance pharmaceutical supply chain sustainability and effectiveness through the adoption of blockchain in KSA hospitals.

\section{Limitations of the Research}

There are two limitations to this research. Firstly, the study will be conducted in the 
context of Saudi Arabia which is a developing country. Secondly, the participants will be selected from the hospitals belonging to three large health providers of the country. Both the limitations may result in less possibility of the findings' generalisability to other hospitals as well as other countries, especially the developed countries.

\section{Future study}

This study will use a qualitative research method and the data will be collected through semi-structured interviews. It is anticipated that the results from this research will assist KSA healthcare authorities in formulating a set of guidelines for blockchain implementation in the pharmaceutical supply chain. In addition, the findings of this study may assist managers, practitioners, consultants and decision makers to understand the use of advanced and modern techniques and approaches which may aid in creating a strong connection among healthcare players.

\section{Conclusion}

This paper presents a theoretical model to study the impact of blockchain implementation on the sustainability and effectiveness of the pharmaceutical supply chain. The researchers pointed out the issues in the current pharmaceutical supply chain management, and explained how blockchain can be used to solve these issues as well as how blockchain can address and promote supply chain sustainability. Although blockchain technology is certainly in its infancy, the researchers are already witnessing progress regarding its implementation in everyday life, mainly in the financial and the pharmaceutical sectors. Nevertheless, this is an ongoing work, and the writers are engaging in a continuing deeper level of research and data collection to ascertain a definitive explanation to the role of blockchain in the sustainability and effectiveness of the pharmaceutical supply chain in KSA.

\section{References}

- Abdullah, Z, Anuar, AIM, Ab Razak, WMW, Aziz, NA \& Hamdan, H 2018, 'The Triple Bottom Line (TBL) studies towards Sustainability Marketing', in 1st Economics and Business International Conference 2017 (EBIC 2017), Atlantis Press.

- Agbo, CC, Mahmoud, QH \& Eklund, JM 'Blockchain technology in healthcare: A systematic review', Multidisciplinary Digital Publishing Institute, p. 56.

- $\quad$ Ahi, P \& Searcy, C 2013, 'A comparative literature analysis of definitions for green and sustainable supply chain management', Journal of Cleaner Production, vol. 52, pp. 329-341.

- Ahmadi, HB, Kusi-Sarpong, S \& Rezaei, J 2017, 'Assessing the social sustainability of supply chains using Best Worst Method', Resources, Conservation and Recycling, vol. 126, pp. 99-106.

- $\quad$ Akhtar, P \& Khan, Z 2015, 'The linkages between leadership approaches and coordination effectiveness', British Food Journal, vol. 117, no. 1, pp. 443-460.

- Al-Hujran, O, Al-Lozi, EM, Al-Debei, MM \& Maqableh, M 2018, 'Challenges of cloud computing adoption from the TOE framework perspective', International Journal of E-Business Research (IJEBR), vol. 14, no. 3, pp. 77-94.

- $\quad$ Alhaddi, H 2015, 'Triple bottom line and sustainability: A literature review', Business and Management Studies, vol. 1, no. 2, pp. 6-10.

- Alhadhrami, Z, Alghfeli, S, Alghfeli, M, Abedlla, JA \& Shuaib, K 'Introducing blockchains for healthcare', IEEE, pp. 14.

- Ally, M \& Wark, N 2019, Learning for Sustainable Development in the Fourth Industrial Revolution, viewed 2/1/2020, <http://oasis.col.org/handle/11599/33 $\underline{93}>$. 
- $\quad$ Alruthia, YS, Alwhaibi, M, Alotaibi, MF, Asiri, SA, Alghamdi, BM, Almuaythir, GS, Alsharif, WR, Alrasheed, HH, Alswayeh, YA \& Alotaibi, AJ 2018, 'Drug shortages in Saudi Arabia: Root causes and recommendations', Saudi Pharmaceutical Journal, vol. 26, no. 7, pp. 947-951.

- Alsaddique, A 2017, 'Future of the pharmaceutical industry in the GCC countries', Integr Mol Med, vol. 4, no. 4, pp. 1-3.

- Alsheibani, S, Cheung, Y \& Messom, C 2018, 'Artificial Intelligence Adoption: AI-readiness at Firm-Level', Artificial Intelligence, vol. 6, pp. 26-2018.

- Alsulame, K, Khalifa, M \& Househ, M 2016, 'E-Health status in Saudi Arabia: A review of current literature', Health Policy and Technology, vol. 5, no. 2, pp. 204-210.

- $\quad$ Alyami, AA 2018, 'Smart e-Health System for Real-time Tracking and Monitoring of Patients, Staff and Assets for Healthcare Decision Support in Saudi Arabia', thesis, Staffordshire University.

- Alzahrani, N \& Bulusu, N 2018, 'Blocksupply chain: A new anti-counterfeiting supply chain using NFC and blockchain', in Proceedings of the 1st Workshop on Cryptocurrencies and Blockchains for Distributed Systems, Munich, Germany, June 15, 2018, pp. 30-35.

- Alzawawi, M 2014, 'Drivers and obstacles for creating sustainable supply chain management and operations', Retrived March, vol. 20, p. 2016.

- Angraal, S, Krumholz, HM \& Schulz, WL 2017, 'Blockchain Technology: Applications in Health Care', Circ Cardiovasc Qual Outcomes, vol. 10, no. 9.

- $\quad$ Ansari, ZN \& Kant, R 2017, 'A state-of-art literature review reflecting 15 years of focus on sustainable supply chain management', Journal of Cleaner Production, vol. 142, pp. 2524-2543.
- Ata, UZ 2015, 'The role of information technology in supply chain sustainability', Journal of Emerging Trends in Economics and Management Sciences, vol. 6, no. 5, pp. 354-358.

- Ayandibu, AO \& Houghton, J 2017, 'External forces affecting Small businesses in South Africa: A case study', Journal of Business and Retail Management Research, vol. 11, no. 2.

- Azadi, M, Jafarian, M, Saen, RF \& Mirhedayatian, SM 2015, 'A new fuzzy DEA model for evaluation of efficiency and effectiveness of suppliers in sustainable supply chain management context', Computers \& Operations Research, vol. 54, pp. 274-285.

- $\quad$ Baah, C \& Jin, Z 2019, 'Sustainable Supply Chain Management and Organizational Performance: The Intermediary Role of Competitive Advantage', J. Mgmt. \& Sustainability, vol. 9, p. 119.

- Bellucci, M, Bini, L \& Giunta, F 2020, 'Implementing environmental sustainability engagement into business: sustainability management, innovation, and sustainable business models', in Innovation Strategies in Environmental Science, Elsevier, pp. 107-143.

- Benazzouz, T, Charkaoui, A \& Echchatbi, A 2019, 'Risks related to the medical supply chain in public hospitals in Morocco: Qualitative study', Le Pharmacien Hospitalier et Clinicien, vol. 54, no. 1, pp. 19-29.

- Bettiga, D, Lamberti, L \& Lettieri, E 2019, 'Individuals' adoption of smart technologies for preventive health care: a structural equation modeling approach', Health care management science, vol., pp. 1-12.

- $\quad$ Bevilacqua, M, Ciarapica, FE, Mazzuto, G \& Paciarotti, C 2013, 'The impact of RFID technology in hospital drug management: An economic and qualitative assessment', International Journal of RF Technologies, vol. 4, no. 3-4, pp. 181-208. 
- Bokolo, AJ 2020, 'Green Information Systems Refraction for Corporate Ecological Responsibility Reflection in ICT Based Firms: Explicating Technology Organization Environment Framework', Journal of Cases on Information Technology (JCIT), vol. 13, no. 1, pp. 1437.

- $\quad$ Boulos, MNK, Wilson, JT \& Clauson, KA 2018, Geospatial blockchain: promises, challenges, and scenarios in health and healthcare, BioMed Central, 1476-072X.

- $\quad$ Brandenburg, M, Govindan, K, Sarkis, J \& Seuring, S 2014, 'Quantitative models for sustainable supply chain management: Developments and directions', European journal of operational research, vol. 233, no. 2, pp. 299-312.

- Bryatov, S \& Borodinov, A 2019, 'Blockchain technology in the pharmaceutical supply chain: researching a business model based on Hyperledger Fabric', in International Conference on "Information Technology and Nanotechnology", Samara, Russia, 2019.

- Chandan, A, Potdar, V \& Rosano, M 2019, 'How Blockchain can help in Supply Chain Sustainability', in Australasian Conference on Information Systems, Perth, Western Australia, 2019.

- Chang, Y-W 2020, 'What drives organizations to switch to cloud ERP systems? The impacts of enablers and inhibitors', Journal of Enterprise Information Management, vol. 33, no. 3.

- Chavali, L, Prashanti, N, Sujatha, K, Rajasheker, G \& Kavi Kishor, P 2018, 'The emergence of blockchain technology and its impact in biotechnology pharmacy and life sciences', Current Trends in Biotechnology and Pharmacy, vol. 123, pp. 304-310.

- Childerhouse, P \& Towill, DR 2003, 'Simplified material flow holds the key to supply chain integration', Omega, vol. 31, no. 1, pp. 17-27.
- $\quad$ Choi, T-M, Wallace, SW \& Wang, Y 2016, 'Risk management and coordination in service supply chains: information, logistics and outsourcing', Journal of the Operational Research Society, vol. 67, no. 2, pp. 159-164.

- Chowdhury, MJM, Colman, A, Kabir, MA, Han, J \& Sarda, P 'Blockchain versus database: a critical analysis', IEEE, pp. 1348-1353.

- $\quad$ Christopher, M 2016, Logistics \& supply chain management, Pearson UK.

- Clancy, H 2017, The blockchain's emerging role in sustainability, GreenBiz, viewed 1/2/2020, <https://www.greenbiz.com/article/bl ockchains-emerging-rolesustainability>.

- Clark, B \& Burstall, R 2018, 'Blockchain, IP and the pharma industry-how distributed ledger technologies can help secure the pharma supply chain', Journal of Intellectual Property Law \& Practice, vol. 13 , no. 7 , pp. 531-533.

- $\quad$ Clauson, KA, Breeden, EA, Davidson, C \& Mackey, TK 2018, 'Leveraging blockchain technology to enhance supply chain management in healthcare', Blockchain in Healthcare Today, vol. 62, pp. 35-45.

- Clohessy, T, Acton, T \& Rogers, N 2019, 'Blockchain adoption: Technological, organisational and environmental considerations', in Business Transformation through Blockchain, Springer, pp. 47-76.

- Cousins, PD, Lawson, B, Petersen, KJ \& Fugate, B 2019, 'Investigating green supply chain management practices and performance', International Journal of Operations \& Production Management, vol. 39 , no. 5 , pp. 767-786.

- $\quad$ Cox, JF, Blackstone Jr, JH \& Spencer, MS 1992, APICS Dictionary, 1992, American Production and Inventory Control Society, Falls Church, Virginia. 
- Davis, FD 1989, 'Perceived usefulness, perceived ease of use, and user acceptance of information technology', MIS quarterly, vol., pp. 319-340.

- De Carvalho, SA 2018, 'Sustainability Dimensions and Public Relations Practices in Public Health System', in Towards Green Campus Operations, Springer, pp. 105-112.

- $\quad$ Dehgani, R \& Navimipour, NJ 2019, 'The impact of information technology and communication systems on the agility of supply chain management systems', Kybernetes, vol. 48, no. 10, pp. 22172236.

- Dubey, R, Gunasekaran, A, Childe, SJ, Papadopoulos, T \& Fosso Wamba, S 2017, 'World class sustainable supply chain management: critical review and further research directions', The International Journal of Logistics Management, vol. 28, no. 2, pp. 332-362.

- Dylan Yaga, PM, Nik Roby, \& Scarfone, K 2018, Blockchain Technology Overview, viewed 12/12/2019, <https://nvlpubs.nist.gov/nistpubs/ir/ 2018/NIST.IR.8202.pdf>.

- Eitiveni, I, Kurnia, S \& Buyya, R 'Sustainable Supply Chain Management: Taxonomy, Gaps, and Future Directions', p. 121.

- El-Din, DM 2019, A Big Egyptian Pharmacy based on Blockchain System, viewed 5/1/2020, <https://www.researchgate.net/public ation/336069858_A_Big_Egyptian_Phar macy based on Blockchain System $>$.

- Elango, GSM 2018, 'The Impact of Information and Communications Technology on Supply chain management in South Indian Small-scale grocery sector', thesis.

- Erdenebold, T, Rho, JJ \& Hwang, YM 2019, 'Blockchain Reference Model and Use Case for Supply Chains within
Enterprise Architecture', 정보화연구 (구 정보기술아키텍처연구), vol. 16, no. 1 , pp. 1-10.

- Evans, JD 2018, 'Improving the Transparency of the Pharmaceutical Supply Chain through the Adoption of Quick Response (QR) Code, Internet of Things (IoT), and Blockchain Technology: One Result: Ending the Opioid Crisis', Pitt. J. Tech. L. \& Pol'y, vol. 19 , p. 35.

- Fenwick, M \& Vermeulen, EP 2019, 'Technology and corporate governance: blockchain, crypto, and artificial intelligence', Tex. J. Bus. L., vol. 48, p. 1.

- $\quad$ Fiaidhi, J, Mohammed, S \& Mohammed, S 2018, 'EDI with blockchain as an enabler for extreme automation', IT Professional, vol. 20 , no. 4 , pp. $66-72$.

- Fiorini, P \& Jabbour, CJC 2017, 'Information systems and sustainable supply chain management towards a more sustainable society: Where we are and where we are going', International Journal of Information Management, vol. 37 , no. 4 , pp. 241-249.

- Galal, NM \& Moneim, AFA 2016, 'Developing sustainable supply chains in developing countries', Procedia Cirp, vol. 48, pp. 419-424.

- Gao, W, Hatcher, WG \& Yu, W 'A survey of blockchain: techniques, applications, and challenges', IEEE, pp. 1-11.

- Georgise, FB, Klause-Dieter, T \& Seifert, M 2014, 'Integrating developing country manufacturing industries into global supply chain', Journal of Industrial Engineering and Management, vol. 7, no. 1.

- Ghadimi, P, Wang, C \& Lim, MK 2019, 'Sustainable supply chain modeling and analysis: Past debate, present problems and future challenges', Resources, Conservation and Recycling, vol. 140, pp. 72-84. 
- Gupte, P, Gupta, S \& Sinha, MAK 2019, 'Medical entity tracking using blockchain technology ', International Journal For Technological Research In Engineering, vol. 6, no. 7, pp. 5169-5172.

- Habib, MM 2017, 'Supply Chain Management (SCM): its implications on manufacturing and service industry', in Proc. Of The Sixth Intl. Conf, On Advances In ESSHBS, USA, February 2017, pp. 5560.

- Haq, I \& Esuka, OM 2018, 'Blockchain Technology in Pharmaceutical Industry to Prevent Counterfeit Drugs', International Journal of Computer Applications, vol. 975, p. 8887.

- Hartley, JL \& Sawaya, WJ 2019, 'Tortoise, not the hare: Digital transformation of supply chain business processes', Business Horizons, vol. 62, no. 6, pp. 707715.

- He, Q, Guan, N, Lv, M \& Yi, W 'On the consensus mechanisms of blockchain/dlt for internet of things', IEEE, pp. 1-10.

- Hellen, K \& Patrick, M 2019, 'Role of information technology on supply chain performance in public institutions in Kenya: a case of the judiciary of Kenya ', International Journal of Logistics and Procurement Management, vol. 1, no. 1.

- Henderson, D, Sheetz, SD \& Trinkle, BS 2012, 'The determinants of interorganizational and internal in-house adoption of XBRL: A structural equation model', International journal of accounting information systems, vol. 13, no. 2, pp. 109-140.

- Heston, T 2017, 'Why Blockchain Technology Is Important for Healthcare Professionals', SSRN Electronic Journal, vol. 1.

- Hsu, C-L \& Lin, JC-C 2016, 'Factors affecting the adoption of cloud services in enterprises', Information Systems and e-Business Management, vol. 14, no. 4, pp. 791-822.
- Humbani, M \& Wiese, M 2018, 'A cashless society for all: Determining consumers' readiness to adopt mobile payment services', Journal of African Business, vol. 19, no. 3, pp. 409-429.

- Iacovou, CL, Benbasat, I \& Dexter, AS 1995, 'Electronic data interchange and small organizations: Adoption and impact of technology', MIS quarterly, vol., pp. 465-485.

- Ijab, MT, Wahab, SMA, Salleh, MAM \& Bakar, AA 'Investigating Big Data Analytics Readiness in Higher Education Using the Technology-OrganisationEnvironment (TOE) Framework', IEEE, pp. 1-7.

- Iqbal, MJ, Geer, MI \& Dar, PA 2017, 'Medicines management in hospitals: a supply chain perspective', Systematic Reviews in Pharmacy, vol. 8, no. 1, p. 80.

- Jacyna-Gołda, I, Izdebski, M, Szczepański, E \& Gołda, P 2018, 'The assessment of supply chain effectiveness', Archives of Transport, vol. 45.

- Jadhav, A, Orr, S \& Malik, M 2019, 'The role of supply chain orientation in achieving supply chain sustainability', International Journal of Production Economics, vol. 217, pp. 112-125.

- Jamil, F, Hang, L, Kim, K \& Kim, D 2019, 'A Novel Medical Blockchain Model for Drug Supply Chain Integrity Management in a Smart Hospital', Electronics, vol. 8, no. 5, p. 505.

- Jochumsen, ML \& Chaudhuri, A 2018, 'Blockchain's impact on supply chain of a pharmaceutical company', in EUROMA Conference 2018, Budapest, Hungary, 28 June 2018.

- $\quad$ K, S, Pandey, P \& Dhanalakshmi, R 2018, 'A Counterfeit Solution for Pharma Supply Chain', EAI Endorsed Transactions on Cloud Systems, vol. 3, no. 11. 
- Kanda, MK \& Iravo, MA 2015, 'Access factors affecting supply chain efficiency of medical supplies in public health centers in Kenya: a case study of public health centers in Elgeyo Marakwet Count', Int J Acad Res Accounting Financ Manag Sci, vol. 5, p. 2.

- Kapoor, D 2018, 'An Overview on Pharmaceutical Supply Chain: A Next Step towards Good Manufacturing Practice', Drug Designing \& Intellectual Properties International Journal, vol. 1, no. 2.

- $\quad$ Kapoor, D, Vyas, R \& Dadarwal, D 2018, 'An Overview on Pharmaceutical Supply Chain: A Next Step towards Good Manufacturing Practice.', Drug Designing \& Intellectual Properties International Journal, vol. 1, no. 2, pp. 49-54.

- Katuwal, GJ, Pandey, S, Hennessey, M \& Lamichhane, B 2018, Applications of Blockchain in Healthcare: Current Landscape \& Challenges, viewed $1 / 11 / 2019$, <https://arxiv.org/abs/1812.02776>.

- Kaur, M, Singh, K \& Singh, D 2020, 'Interconnection between implementation and competitive dimensions of SCM and combined approach (TQM-SCM) in context of Indian manufacturing industry', World Journal of Science, Technology and Sustainable Development, vol. ahead-ofprint No.

- Khalifa, M 2014, 'Technical and human challenges of implementing hospital information systems in Saudi Arabia', Journal of Health Informatics in Developing Countries, vol. 8, no. 1.

- Khuntia, J, Saldanha, TJ, Mithas, S \& Sambamurthy, V 2018, 'Information technology and sustainability: Evidence from an emerging economy', Production and Operations Management, vol. 27, no. 4, pp. 756-773.

- Koteska, B, Karafiloski, E \& Mishev, A 'Blockchain Implementation Quality Challenges: A Literature', pp. 11-13.
- Kouhizadeh, M \& Sarkis, J 2018, 'Blockchain practices, potentials, and perspectives in greening supply chains', Sustainability, vol. 10, no. 10, p. 3652.

- Krause, DR, Vachon, S \& Klassen, RD 2009, 'Special topic forum on sustainable supply chain management: introduction and reflections on the role of purchasing management', Journal of Supply Chain Management, vol. 45, no. 4, pp. 18-25.

- Kshetri, N 2018a, '1 Blockchain's roles in meeting key supply chain management objectives', International Journal of Information Management, vol. 39, pp. 8089.

- Kshetri, N 2018b, 'Blockchain and electronic healthcare records [cybertrust]', Computer, vol. 51, no. 12, pp. 59-63.

- Kumar, A, Choudhary, D, Raju, MS, Chaudhary, DK \& Sagar, RK 'Combating Counterfeit Drugs: A quantitative analysis on cracking down the fake drug industry by using Blockchain technology', IEEE, pp. 174-178.

- Kumar, S, Liu, J \& Demirag, OC 2016, 'National culture's impact on effectiveness of supply chain disruption management', Journal of Applied Business and Economics, vol. 17, no. 4.

- Kurki, J 2016, 'Benefits and guidelines for utilizing blockchain technology in pharmaceutical supply chains: case Bayer Pharmaceuticals', thesis.

- $\quad$ Li, S, Ragu-Nathan, B, Ragu-Nathan, T \& Rao, SS 2006, 'The impact of supply chain management practices on competitive advantage and organizational performance', Omega, vol. 34, no. 2, pp. 107-124.

- $\quad$ Lin, K-P, Tseng, M-L \& Pai, P-F 2018, 'Sustainable supply chain management using approximate fuzzy DEMATEL method', Resources, Conservation and Recycling, vol. 128, pp. 134-142. 
- Lummus, RR \& Vokurka, RJ 1999, 'Defining supply chain management: a historical perspective and practical guidelines', Industrial Management \& Data Systems, vol. 99, no. 1.

- $\quad$ Lund, EH, Jaccheri, L, Li, J, Cico, O \& Bai, X 'Blockchain and sustainability: a systematic mapping study', IEEE, pp. 1623.

- Mani, V, Gunasekaran, A \& Delgado, C 2018, 'Enhancing supply chain performance through supplier social sustainability: An emerging economy perspective', International Journal of Production Economics, vol. 195, pp. 259272.

- Mathur, B, Gupta, S, Meena, ML \& Dangayach, G 2018, 'Healthcare supply chain management: literature review and some issues', Journal of Advances in Management Research, vol. 15, no. 3.

- Mattila, J, Seppälä, T \& Holmström, J 2016, 'Product-centric information management: A case study of a shared platform with blockchain technology', in Industry Studies Association Conferences Minneapolis, MN, USA, 25-26 May 2016.

- $\quad$ Menezes, R, Olia, F, Gupta, I \& Gawade, A 2019, 'Monitoring Medicine Delivery Supply Chain Using Blockchain With IoT', Compliance Engineering Journal, vol. 10 , no. 11.

- Meng, J, Elliott, KM \& Hall, MC 2009, 'Technology readiness index (TRI): Assessing cross-cultural validity', Journal of International Consumer Marketing, vol. 22, no. 1, pp. 19-31.

- $\quad$ Mezquita, Y'Internet of Things Platforms Based on Blockchain Technology: A Literature Review', Springer, pp. 205208.

- Ministry of health 2019, National ehealth strategy, Ministry of health viewed 20/12/2019, <https://www.moh.gov.sa/en/Ministry Lnehs/Pages/SustainableDevelopment. aspx>.
- Montecchi, M, Plangger, K \& Etter, M 2019, 'It's real, trust me! Establishing supply chain provenance using blockchain', Business Horizons, vol. 62, no. 3, pp. 283-293.

- Nabelsi, V \& Gagnon, S 2017, 'Information technology strategy for a patient-oriented, lean, and agile integration of hospital pharmacy and medical equipment supply chains', International journal of production research, vol. 55, no. 14, pp. 3929-3945.

- Namasudra, S, Deka, GC, Johri, P, Hosseinpour, M \& Gandomi, AH 2020, 'The revolution of blockchain: State-ofthe-art and research challenges', Archives of Computational Methods in Engineering, vol. 16, no. 3.

- Napitupulu, D, Syafrullah, M, Rahim, R, Abdullah, D \& Setiawan, M 'Analysis of user readiness toward ICT usage at small medium enterprise in south tangerang', IOP Publishing, p. 012042.

- Nayyar, GML, Breman, JG, Mackey, TK, Clark, JP, Hajjou, M, Littrell, M \& Herrington, JE 2019, 'Falsified and Substandard Drugs: Stopping the Pandemic', Am J Trop Med Hyg, vol. 100, no. 5, pp. 1058-1065.

- Nguyen, TTH, Taskin, N, Scahill, S \& Pauleen, D 2019, 'Antecedents of Supply Chain Information Visibility: The Complementarity Effect of IT Integration Capability and Interpersonal Communication Capability', in Twentyfifth Americas Conference on Information Systems, Cancun, 2019.

- Niforos, M 2017, 'Beyond Fintech: Leveraging Blockchain for More Sustainable and Inclusive Supply Chains', International Finance Corporation (IFC) EM Compass Note, vol. 43 , pp. $45-46$.

- OECD 2019, 'Blockchain technologies as a digital enabler for sustainable infrastructure', vol. 16. 
- $\quad$ Olnes, S, Ubacht, J \& Janssen, M 2017, Blockchain in government: Benefits and implications of distributed ledger technology for information sharing, Elsevier, 0740-624X.

- Özçelik, F \& Öztürk, BA 2014, 'A research on barriers to sustainable supply chain management and sustainable supplier selection criteria', Dokuz Eylul University Journal of Graduate School of Social Sciences, vol. 16, no. 2.

- $\quad$ Pagell, M \& Shevchenko, A 2014, 'Why research in sustainable supply chain management should have no future', Journal of Supply Chain Management, vol. 50 , no. 1 , pp. $44-55$.

- Parasuraman, A 2000, 'Technology Readiness Index (TRI) a multiple-item scale to measure readiness to embrace new technologies', Journal of service research, vol. 2 , no. 4 , pp. 307-320.

- $\quad$ Parung, J 2019, 'The use of blockchain to support sustainable supply chain strategy', in IOP Conference Series: Materials Science and Engineering, IOP Publishing, Bali, Indonesia, 22-23 August 2019.

- Pashkov, V \& Soloviov, 0 'Legal implementation of blockchain technology in pharmacy', EDP Sciences, p. 01027.

- Pflaum, A, Prockl, G, Bodendorf, F \& Chen, H 2018a, 'The Digital Supply Chain of the Future: From Drivers to Technologies and Applications', in Proceedings of the 51st Hawaii International Conference on System Sciences, Hawaii, January 2018.

- Pflaum, A, Prockl, G, Bodendorf, F \& Chen, H 2018b, 'Introduction to the Minitrack on The Digital Supply Chain of the Future: Technologies, Applications and Business Models', in Proceedings of the 51st Hawaii International Conference on System Sciences, Hawaii, January 2018.
- Plotnikov, V \& Kuznetsova, V 'The Prospects for the Use of Digital Technology "Blockchain" in the Pharmaceutical Market', EDP Sciences, p. 02029.

- $\quad$ Privett, N \& Gonsalvez, D 2014, 'The top ten global health supply chain issues: perspectives from the field', Operations Research for Health Care, vol. 3, no. 4, pp. 226-230.

- Queiroz, MM, Telles, R \& Bonilla, SH 2019, 'Blockchain and supply chain management integration: A systematic review of the literature', Supply Chain Management: An International Journal, vol. 25 , no. 2 .

- Radanović, I \& Likić, R 2018, 'Opportunities for use of blockchain technology in medicine', Applied health economics and health policy, vol. 16, no. 5, pp. 583-590.

- Raj, R, Rai, N \& Agarwal, S 'Anticounterfeiting in Pharmaceutical Supply Chain by establishing Proof of Ownership', IEEE, pp. 1572-1577.

- Rajeev, A, Pati, RK, Padhi, SS \& Govindan, K 2017, 'Evolution of sustainability in supply chain management: A literature review', Journal of Cleaner Production, vol. 162, pp. 299-314.

- Rana, D \& Alayed, RS 2018, 'Green Business: Sustainability within Saudi Vision', International Journal of Advance Study and Research Work, vol. 1, no. 9.

- $\quad$ Randall, D, Goel, P \& Abujamra, R 2017, 'Blockchain applications and use cases in health information technology', J Health Med Informat, vol. 8, no. 276, p. 2.

- Rasool, Y, Ahmad, W \& Nazam, M 2016, 'Empirical study on implementation of sustainable supply chain management: a case of textile sector', International Journal of Sustainability Management and Information Technologies, vol. 2, no. 4, pp. 21-27. 
- Rehman, AU, Al-Zabidi, A, AlKahtani, M, Umer, U \& Usmani, YS 2020, 'Assessment of Supply Chain Agility to Foster Sustainability: Fuzzy-DSS for a Saudi Manufacturing Organization', Processes, vol. 8, no. 5, p. 577.

- Rinjany, DK 2020, 'Does Technology Readiness and Acceptance Induce more Adoption of E-Government? Applying the UTAUT and TRI on an Indonesian Complaint-Based Application', Policy \& Governance Review, vol. 4, no. 1, pp. 6886.

- Rogers, EM 2010, Diffusion of innovations, Simon and Schuster.

- $\quad$ Saberi, S, Kouhizadeh, M, Sarkis, J \& Shen, L 2019, 'Blockchain technology and its relationships to sustainable supply chain management', International journal of production research, vol. 57, no. 7 , pp. 2117-2135.

- $\quad$ Sadiku, MN, Eze, KG \& Musa, SM 2018, 'Block chain Technology in Healthcare', International Journal of Advances in Scientific Research and Engineering, vol. 4.

- $\quad$ Saeed, MA \& Kersten, W 2019, 'Drivers of sustainable supply chain management: identification and classification', Sustainability, vol. 11, no. 4, p. 1137.

- Samuga, A 2020, How blockchain can add value to the pharmaceutical industry, European pharmaceutical manufacturer, viewed 1/6/202, <https://www.epmmagazine.com/opini on/how-blockchain-can-add-value-tothe-pharmaceutical-industry/>.

- Saudi Press Agency 2018, Riyadh Municipality signs an agreement to implement "Blockchain" technology to enhance the quality of services, Saudi Press Agency, viewed 1/2/2020, <https://www.spa.gov.sa/1783621>.

- $\quad$ Saudi Vision 2019, National Industry and Logistics Development Program, Saudi vision 2030, viewed 6/12/2019,
$<$ https://vision2030.gov.sa/en/progra $\underline{\mathrm{ms} / \text { NIDLP }}>$.

- Schmidt, CG \& Wagner, SM 2019, 'Blockchain and supply chain relations: A transaction cost theory perspective', Journal of purchasing and supply management, vol. 25, no. 4, pp. 1-13.

- Schöner, MM, Kourouklis, D, Sandner, P, Gonzalez, E \& Förster, J 2017, Blockchain technology in the pharmaceutical industry, viewed 23/12/2019, $<$ https://pdfs.semanticscholar.org/e09 1/f69e35d947d841c78c069e6c0e521df 6180d.pdf $>$.

- $\quad$ Schwab, K 2015, Will the fourth industrial revolution have a human heart, World Economic Forum.

- Scott, T, Post, AL, Quick, J \& Rafiqi, S 2018, 'Evaluating feasibility of blockchain application for DSCSA compliance', SMU Data Science Review, vol. 1, no. 2, p. 4 .

- Seebacher, S \& Schüritz, R 'Blockchain technology as an enabler of service systems: A structured literature review', Springer, pp. 12-23.

- Shrikant, GP 2019, 'Traceability and detection of counterfeit medicine supply chain through Blockchain', Journal of the Gujarat Research Society, vol. 21, no. 8, pp. 143-149.

- $\quad$ Sidhu, j 2020, 'Sustainability Pillars With Reference To Spiritual Enviournment', Studies in Indian Place Names, vol. 40, no. 40, pp. 1777-1781.

- Sinclair, D, Shahriar, H \& Zhang, C 'Security requirement prototyping with hyperledger composer for drug supply chain: a blockchain application', ACM, pp. 158-163.

- Siyal, A, Junejo, A, Zawish, M, Ahmed, K, Khalil, A \& Soursou, G 2019, 'Applications of Blockchain Technology in Medicine and Healthcare: Challenges and Future Perspectives', Cryptography, vol. 3 , no. 1 , p. 3 .

Shaker ALHARTHI,Paul R. CEROTTI and Shaghayegh MALEKI FAR (2020), Journal of Supply Chain and Customer Relationship Management, DOI: 10.5171/2020.562376 
- Sonnenwald, DH, Maglaughlin, KL \& Whitton, MC 'Using innovation diffusion theory to guide collaboration technology evaluation: work in progress', IEEE, pp. 114-119.

- Soundarya, K, Pandey, P \& Dhanalakshmi, R 2018, 'A Counterfeit Solution for Pharma Supply Chain', EAI Endorsed Transactions on Cloud Systems, vol. 3, no. 11.

- $\quad$ Starbuck, W 1976, 1976" Organizations and their environments" in Handbook of industrial and organizational psychology. MD Dunnette (ed.), 1069-1123. Chicago: Rand McNally.

- $\quad$ Suhail, S, Pandey, SR \& Hong, CS 2019, 'A Provenance-based Solution for Tracking Sensor Data in the Pharmaceutical Supply Chain', 한국정보과학회 학술발표논문집, vol., pp. 281-283.

- Sulkowski, AJ 2018, 'Blockchain, law, and business supply chains: The need for governance and legal frameworks to achieve sustainability', Delaware Journal of Corporate Law, vol. 43, no. 2.

- Tasatanattakool, P \& Techapanupreeda, C 'Blockchain: Challenges and applications', IEEE, pp. 473-475.

- Thöni, A \& Tjoa, AM 2017, 'Information technology for sustainable supply chain management: a literature survey', Enterprise Information Systems, vol. 11, no. 6, pp. 828-858.

- Tijan, E, Aksentijević, S, Ivanić, K \& Jardas, M 2019, 'Blockchain technology implementation in logistics', Sustainability, vol.11, no. 4, p. 1185.

- Tornatzky, LG, Fleischer, M \& Chakrabarti, AK 1990, Processes of technological innovation, Lexington books.

- Touboulic, A \& Walker, H 2015, 'Theories in sustainable supply chain management: a structured literature review', International Journal of Physical Distribution \& Logistics Management, vol. 45 , no. $1 / 2$, pp. 16-42.

- Useem, M 1993, 'Management commitment and company policies on education and training', Human Resource Management, vol. 32, no. 4, pp. 411-434.

- Uthayakumar, R \& Priyan, S 2013, 'Pharmaceutical supply chain and inventory management strategies: Optimization for a pharmaceutical company and a hospital', Operations Research for Health Care, vol. 2, no. 3, pp. 52-64.

- Van Rijmenam, M 2019, The Organisation of Tomorrow: How AI, blockchain and analytics turn your business into a data organisation, Routledge.

- Venkatesh, V, Kang, K, Wang, B, Zhong, RY \& Zhang, A 2020, 'System architecture for blockchain based transparency of supply chain social sustainability', Robotics and ComputerIntegrated Manufacturing, vol. 63, p. 101896.

- Wamba, SF \& Queiroz, MM 2020, Blockchain in the operations and supply chain management: Benefits, challenges and future research opportunities, Elsevier, 0268-4012.

- Wang, X, Lin, H \& Tian, M 2019, 'Corporate Sustainability Performance of Chinese Firms: An Empirical Analysis from a Social Responsibility Perspective', Emerging Markets Finance and Trade, vol., pp. 1-12.

- Wang, Y, Han, JH \& Beynon-Davies, P 2019, 'Understanding blockchain technology for future supply chains: A systematic literature review and research agenda', Supply Chain Management: An International Journal, vol. 24, no. 1, pp. 62-84.

- Westjohn, SA, Arnold, MJ, Magnusson, P, Zdravkovic, S \& Zhou, JX 2009, 'Technology readiness and usage: a 
global-identity perspective', Journal of the Academy of Marketing Science, vol. 37 , no. 3 , pp. $250-265$.

- White, GR 2017, 'Future applications of blockchain in business and management: A Delphi study', Strategic Change, vol. 26, no. 5, pp. 439-451.

- WHO 2017, Global surveillance and monitoring system for substandard and falsified medical products, World Health Organization, viewed 30/5/2020, <https://www.who.int/medicines/regu lation/ssffc/publications/GSMSreport E N.pdf?ua $=1>$.

- Wittstruck, D \& Teuteberg, F 2012, 'Understanding the Success Factors of Sustainable Supply Chain Management: Empirical Evidence from the Electrics and Electronics Industry', Corporate Social Responsibility and Environmental Management, vol. 19, no. 3, pp. 141-158.

- Wong, L-W, Leong, L-Y, Hew, J-J, Tan, GW-H \& Ooi, K-B 2019, 'Time to seize the digital evolution: Adoption of blockchain in operations and supply chain management among Malaysian SMEs', International Journal of Information Management, vol., p. 101997.

- Wüst, K \& Gervais, A 2018, 'Do you need a Blockchain?', in 2018 Crypto Valley Conference on Blockchain Technology (CVCBT), IEEE, Zug, Switzerland, 08 November 2018, pp. 45-54.

- Yamoah, FA 2019, 'Sustainability in supply and value chain management', in Incorporating Sustainability in Management Education, Springer, pp. 167-193.

- $\quad$ Zhang, R, George, A, Kim, J, Johnson, V \& Ramesh, B 2019, 'Benefits of Blockchain Initiatives for Value-Based Care: Proposed Framework', J Med Internet Res, vol. 21, no. 9, p. e13595.

- Zheng, Z, Xie, S, Dai, H-N, Chen, X \& Wang, $\mathrm{H}$ 2018, 'Blockchain challenges and opportunities: A survey', International Journal of Web and Grid Services, vol. 14, no. 4 , pp. 352-375.

Shaker ALHARTHI,Paul R. CEROTTI and Shaghayegh MALEKI FAR (2020), Journal of Supply Chain and Customer Relationship Management, DOI: 10.5171/2020.562376 